Vol.2, No. 1, Jan. 2019

\title{
PENGARUH TRANSAKSI HUBUNGAN ISTIMEWA, TINGKAT USAHA, DAN UKURAN PERUSAHAAN TERHADAP KINERJA PERUSAHAAN
}

\author{
Sasmita Sari Ardaninggar \\ Universitas Pamulang \\ Email : ardaninggar.sasmita@gmail.com
}

\begin{abstract}
The research aims to determine the influence of related party transaction, leverage and firm size on the the firm performance. The related party transaction often being misused to increase the profit for management and controlling shareholder. On the other hand, it is considered as a tool to create efficiency for the operational of the company. To prevent all of the negative use, the company needs leverage as external protection. In addition, the firm size will be added into this research as control variable like leverage do. The performance will be assessed with Return on Equity that represented accounting method and Tobin's $Q$ that represented market method. This research will be focused on property and real estate sector listed in Indonesia Stock Exchange from 2015 to 2017. The result shown that the related party transaction has positive impact on the Tobin's $Q$ but no impact on ROE. The leverage has positive impact on both Tobin's $Q$ and $R O E$ which means higher leverage will bring higher protection from the external party. However, the firm size has negative impact on the Tobin's $Q$ but positive impact on ROE.
\end{abstract}

Keywords : Related Party Transaction, Leverage, Firm Size, ROE, Tobin's $Q$

\begin{abstract}
Abstrak
Tujuan penelitian ini adalah untuk mengetahui pengaruh transaksi hubungan istimewa, tingkat utang dan ukuran perusahaan terhadap kinerja perusahaan. Transaksi hubungan istimewa seringkali disalahgunakan untuk meningkatkan keuntungan manajemen dan pemegang saham mayoritas yang tentunya akan berdampak pada penilaian perusahaan tetapi transaksi ini juga dapat dipandang sebagai alat untuk menciptakan operasional perusahaan yang lebih efisien. Untuk mencegah terjadinya penyalahgunaan atas transaksi ini, diperlukan adanya pengawasan dari luar, salah satunya melalui tingkat utang. Ukuran perusahaan pun menjadi indikator besarnya transaksi ini dilakukan. Kinerja perusahaan akan diukur dengan Tingkat Pengembalian Ekuitas (ROE) sebagai salah satu metode akuntansi dan Tobin's Q sebagai salah satu metode pasar. Penelitian ini dilakukan pada perusahaan properti dan real estate yang terdaftar dalam Bursa Efek Indonesia tahun 2015-2017. Dalam hasil penelitian ini, transaksi hubungan
\end{abstract}


istimewa berpengaruh positif terhadap Tobin's Q tetapi tidak berpengaruh pada ROE. Tingkat utang atau leverage berpengaruh positif baik pada ROE maupun Tobin's Q yang menandakan adanya pengawasan yang ketat dari eksternal terutama yang berkaitan dengan transaksi hubungan istimewa. Sedangkan, ukuran perusahaan berpengaruh negatif terhadap Tobin's Q tetapi memiliki pengaruh positif terhadap ROE.

Kata kunci: Transaksi Hubungan Istimewa, Tingkat Utang, Ukuran Perusahaan, ROE, Tobin's Q

\section{PENDAHULUAN}

Laporan keuangan merupakan sarana informasi yang diterbitkan oleh perusahaan kepada pihak pengambil keputusan, baik internal maupun eksternal, mengenai keseluruhan aktifitas ekonomi dan teknis selama satu siklus operasi. Informasi dalam laporan keuangan memberikan gambaran dan proyeksi bagaimana performa atau kinerja perusahaan pada tahun tersebut dan tahun yang akan datang. Adapun penyajian informasi keuangan haruslah mengikuti standarstandar akuntansi yang berlaku, dimana di Indonesia disajikan dalam Pernyataan Standar Akuntansi Keuangan (PSAK). Menurut PSAK, salah satu syarat laporan keuangan dikatakan baik adalah apabila informasi disajikan dan diungkap secara menyeluruh (full disclosure).

Merujuk pada prinsip akuntansi, laporan keuangan harus disajikan dan diungkap secara menyeluruh (full disclosure) baik pengungkapan yang bersifat wajib (mandatory disclosure) maupun pengungkapan tambahan (voluntary disclosure) (Lang \& Lundholm, 1996). Salah satu variabel yang akan digunakan dalam penelitian ini adalah transaksi hubungan istimewa, yang merupakan bagian dari kelompok pengungkapan wajib seperti yang tercantum dalam PSAK No. 7 Revisi 2010. Transaksi antara pihak-pihak yang memiliki hubungan istimewa terwujud karena adanya transfer tanpa perhitungan harga atas sumber daya dan kewajiban.

Untuk beberapa kasus, transaksi hubungan istimewa seringkali dipergunakan dalam penilaian kinerja suatu perusahaan. Pentingnya penilaian atas kinerja akan mempengaruhi kelangsungan perusahaan dikarenakan dengan semakin meningkatnya nilai perusahaan maka akan berdampak pada peningkatan kemakmuran bagi pemegang saham dan perusahaan (Horne, 1998; Animah \& Ramadhani, 2010). Peningkatan nilai perusahaan dapat direpresentasikan melalui tingginya harga pasar saham dan rasio keuangan perusahaan tersebut. Hal ini menunujukkan bahwa perusahaan dianggap mampu mengelola resiko dan memiliki sinyal positif mengenai pertumbuhan perusahaan dikemudian hari. Dewasa ini, terdapat berbagai instrumen dalam menilai suatu perusahaan, baik dengan metode akuntansi maupun dengan metode pasar.

Seperti yang telah diterangkan sebelumnya bahwa transaksi hubungan istimewa juga menjadi salah satu indikator penilaian perusahaan, menandakan perannya yang dianggap penting. Transaksi ini dibolehkan dan umum dilakukan oleh perusahaan, tapi seringkali dianggap negatif sehingga berdampak pada nilai perusahaan. Transaksi hubungan istimewa mengindikasi terjadinya aggressive 
accounting yang memungkinkan perusahaan untuk menaikkan laba dengan sewenang-wenang (Sherman \& Young, 2001). Selain itu, transaksi ini dianggap sebagai alat untuk mengekspropriasi kekayaan perusahaan dari pemegang saham minoritas kepada pemegang saham mayoritas dengan mempengaruhi kondisikondisi dari perjanjian transaksi sesuai dengan kepentingan pribadi atau seringkali disebut sebagai tunneling (McCahery \& Vermeulen, 2014). Sebut saja kasus penyelewengan atas transaksi hubungan istimewa melalui transfer kas yang dilakukan kepala Bank BRI Unit Tapung Raya pada tahun 2011 yang menyebabkan hilangnya kas sebesar 1.6 miliar rupiah. Kepala BRI Tapung Raya melakukan transfer fiktif ke BRI Cabang Bangkinang dan mencatatnya sebagai transaksi hubungan istimewa. Kejadian in terungkap setelah internal BRI Cabang Bangkinang melihat adanya kejanggalan atas transaksi tersebut.

Di sisi lainnya, transaksi hubungan istimewa dianggap dapat membantu operasional perusahaan menjadi lebih efisien dan efektif (Gordon \& Henry, 2005; Hayati, 2011), contohnya yang berkaitan dengan kontrak kerjasama antara perusahaan yang mempunyai hubungan istimewa. Contoh lain adalah dana pinjaman rendah bunga akan cepat cair, pajak yang rendah dan turunnya biaya modal akibat adanya transfer pricing dalam hal ini dapat berupa kegiatan pembelian dan penjualan kepada pihak hubungan istimewa (Ryngaert \& Thomas, 2007). Seperti halnya pada kasus PT Toyota Manufaktur yang melakukan pembelian dengan harga murah kepada pihak hubungan istimewa sehingga pada akhir periode pembukuan, Toyota mencatatkan nilai laba yang positif dibandingkan dengan perusahaan sejenis di luar negeri. Buysschaert (2004) juga mengemukakan bahwa transfer ekuitas intergroup dapat meningkatkan nilai bagi pemegang saham non pengendali. Bahkan dalam penelitian Farahmita (2011) dan penelitian lanjutan yang dilakukan oleh Gordon, Henry, Reed \& Louwers (2007) menegaskan bahwa transaksi hubungan istimewa tidak mengindikasikan adanya kecurangan dan manajemen laba yang berdampak pada penurunan nilai perusahaan.

Transaksi hubungan istimewa seringkali menimbulkan konflik internal antara pemegang saham (mayoritas dan minoritas) dan manajemen karena adanya perbedaan kepentingan dan keinginan yang akan dicapai. Manajemen selaku pihak yang secara langsung mengelola dan menjalankan roda usaha dituntut untuk dapat meningkatkan keuntungan pemegang saham, tetapi di sisi lain mereka juga memiliki keinginan yang sama sebagai bentuk balas jasa atas usaha mereka dalam kegiatan pengelolaan perusahaan. Hal ini sejalan dengan teori keagenan menurut Jensen \& Meckeling (1976).

Perusahaan dapat meminimalisir konflik tersebut melalui mekanisme pengawasan ekternal berupa tingkat utang (leverage). Tingkat utang merupakan bagian dari sumber pembiayaan perusahaan, diputuskan berdasarkan analisis standar pembiayaan perusahaan. Biaya akan muncul lebih besar apabila rasio utang melebihi standar yang diberlakukan sehingga mempengaruhi stuktur modal perusahaan

Perlunya rasio keuangan untuk menilai suatu kinerja perusahaan sehingga membantu pengambilan keputusan dalam pemberian pinjaman oleh kreditor. Dalam hal ini perlunya tingkat utang (leverage) sebagai mekanisme kontrol dan 
pengawas terhadap aktivitas transaksi yang dilakukan oleh perusahaan. Dengan adanya leverage maka dimungkinkan terjadinya penyalahgunaan dan penyelewengan semakin kecil (Kohlbeck \& Mayhew,2004; Myers, 2001). Kreditor sebagai pemberi utang akan memberikan ekstra pengawasan terhadap jalannya usaha dengan tujuan agar perusahaan sebagai debitor tidak mengalami gagal bayar baik bunga maupun pokok pinjaman.

Ukuran perusahaan dapat pula dijadikan sebagai faktor dalam penelitian karena besaran nilai transaksi dipengaruhi oleh skala usaha. Semakin besar skala suatu perusahaan memungkinkan akan semakin besar jumlah transaksi hubungan istimewa yang dilakukan yang nantinya akan mempengaruhi dalam kinerja perusahaan. Dalam beberapa penelitian sebelumnya ukuran perusahaan yang semakin besar akan memberikan dampak positif kepada kinerja perusahaan. Hal ini dikarenakan perusahaan dianggap mengalami perkembangan sehingga investor akan merespon positif dan kinerja perusahaan akan meningkat (Prijanto, Veno \& Chuzaimah (2017); Arisadi, Djumahir \& Djazuli (2013); Sujoko \& Subiantoro, 2007). Akan tetapi Chen \& Steiner (2000); Siallagan \& Mas Ud (2006) menyatakan sebaliknya bahwa semakin besar ukuran perusahaan maka akan semakin besar memiliki atau menghadapi resiko yang lebih besar dibandingkan dengan perusahaan kecil.

Berdasarkan latar belakang yang telah disebutkan sebelumnya, maka tujuan penelitian ini difokuskan pada kaitan antara transaksi hubungan istimewa, tingkat utang dan ukuran perusahaan dengan nilai perusahaan, apakah besaran ketiga variabel akan berbanding lurus, berbanding terbalik atau bahkan tidak memiliki dampak dengan kinerja perusahaan. Penelitian mengenai topik ini sudah banyak dilakukan tetapi masih sedikit jumlah penelitian yang dilakukan di Indonesia.

\section{KERANGKA TEORITIS DAN PENGEMBANGAN HIPOTESIS}

\subsection{Teori Keagenan}

Teori keagenan merupakan dasar yang digunakan pada praktik-praktik bisnis yang dikembangkan pertaman kali oleh Jensjjen dan Meckling (1976), Teori ini merupakan gabungan dari berbagai teori, yaitu ekonomi, sosiologi, organisasi dan keputusan. Teori ini muncul karena adanya pebedaan kepentingan antara agen (manajemen) dan pemilik (pemegang saham). Agen sebagai pihak yang menjalankan perusahaan menguasai informasi dibandingkan pemiliki sebagai akibatnya agen menginginkan insentif yang lebih. Agen memiliki kuasa untuk menmbuka atau menyembunyikan informasi terkait bisnis kepada pemilik.

Ketidakseimbangan informasi tidak hanya terjadi antara agen dan pemilik perusahaan, tetapi dapat terjadi antara manajemen dan pemegang saham mayoritas dengan pemegang saham minoritas. Pemegang saham mayoritas memiliki akses informasi kepada manajemen, yang tentunya akan menciptakan resiko terjadinya tunneling kepada pemegang saham minoritas. 
Vol.2, No. 1, Jan. 2019

\subsection{Transaksi Hubungan Istimewa}

Seperti yang telah dijelaskan sebelumnya, berdasarkan PSAK No. 7 Revisi 2010 transaksi hubungan istimewa adalah proses pengalihan harta dan kewajiban antar pihak yang memiliki kendali atas pihak lain baik secara keuangan maupun operasional perusahaan. mempunyai pengaruh signifikan atas pihak lain dalam mengambil keputusan keuangan dan operasional. Transaksi ini muncul dari berbagai macam aktivitas, umumnya berasal dari kegiatan penjualan, pembelian, utang dan piutang.

Adapun PSAK No.7 revisi 2010 menjelaskan kelompok yang termasuk dalam pihak-pihak yang memiliki hubungan istimewa diantaranya adalah associate company, intermediaries, pemegang saham mayoritas dan key employee.

\subsection{Tingkat Utang}

Aktivitas operasional perusahaan dapat dibiayai melalui kebijakan tingkat utang atau leverage. Pembiayaan melalui utang diputuskan atas nilai rasio utang yang lebih rendah dari standar yang telah ditetapkan. Tujuannya adalah untuk menjaga struktur modal perusahaan dan besaran biaya yang akan muncul dikemudian hari.

Utang yang diberikan oleh kreditur dapat mewakili fungsi pihak eksternal sebagai pengawas atas jalannya roda perusahaan. Hal ini berkaitan dengan kemampuan perusahaan dalam melunasi utangnya pada kreditur. Sehingga dengan adanya pengawasan tersebut diharapkan kinerja perusahaan menjadi semakin baik. Menurut Myers (2001) semakin tinggi tingkat utang, kinerja perusahaan dianggap semakin meningkat atau membaik. Tidak hanya itu saja, nilai utang yang semakin besar mengindikasikan perusahaan memiliki tambahan sumber dana yang semakin banyak sehingga memiliki kesempatan untuk memaksimalkan operasional usahanya untuk menciptakan laba yang tinggi dan pembagian deviden yang lebih besar lagi (Kristianti, 2018; Ludijanto, Handayani \& Hidayat, 2014; Sulong et al, 2013)

Bertentangan dengan pendapat yang dikemukakan oleh Kristiana (2014) utang yang semakin besar akan menimbulkan risiko gagal bayar yang semakin tinggi. Dirgantara \& Lubis (2013) mengungkapkan suatu pembahan nilai utang disebabkan adanya performa perusahaan yang kurang baik atau laba negatif.

\subsection{Kinerja Perusahaan}

Tujuan dari pelaksanaan sebuah perusahaan adalah memperoleh laba yang maksimum, baik jangka pendek maupun jangka panjang. Dalam rangka meraih laba yang maksimum, perusahaan harus mampu meningkatkan kinerjanya. Penilaian atas kinerja perusahaan sangat penting dilakukan karena dengan semakin meningkatnya nilai perusahaan maka akan berdampak pada peningkatan kemakmuran bagi pemegang saham dan perusahaan (Horne, 1998; Animah dan Ramadhani, 2010). Menurut Ikatan Akuntan Indonesia (IAI) informasi mengenai kinerja perusahaan dapat membantu memprediksikan kapasitas sumber daya perusahaan dalam menghasilkan kas diperiode yang akan datang. Peningkatan 
kinerja perusahaan dapat direpresentasikan melalui tingginya harga pasar saham perusahaan tersebut. Hal ini menunujukkan bahwa perusahaan dianggap mampu mengelola resiko dan memiliki sinyal positif mengenai pertumbuhan perusahaan dikemudian hari.

Beragam cara tersedia untuk melalukan penilaian atas kinerja perusahaan, contohnya Return on Equity (ROE) dan Tobin's Q. ROE adalah penilaian kinerja berdasarkan metode akuntansi atau umumnya disebut sebagai rasio profitabilitas yang mengukur seberapa besar kemampuan penggunaan equity dapat menghasilkan laba bagi perusahaan. ROE yang positif mengindikasikan perusahaan mampu mengoptimalkan investasi modal ke dalam ekuitas sehingga dapat menciptakan laba tahun berjalan yang positif, begitu juga sebaliknya..

Sedangkan Tobin's Q merupakan contoh dalam pengukuran metode pasar. Metode penilaian perusahaan ini dinamai sama dengan penciptanya merupakan seorang ekonom dari Amerika Serikat yang menghitung nilai pasar aset (total nilai pasar saham yang beredar dengan utang). Model ini sering digunakan dalam melakukan proyeksi perusahaan karena tidak adanya estimasi dalam menugukur tingkat pengembalian dan biaya marjin.

\subsection{Kerangka Teori}

Berikut adalah skema kerangka teori penelitian:

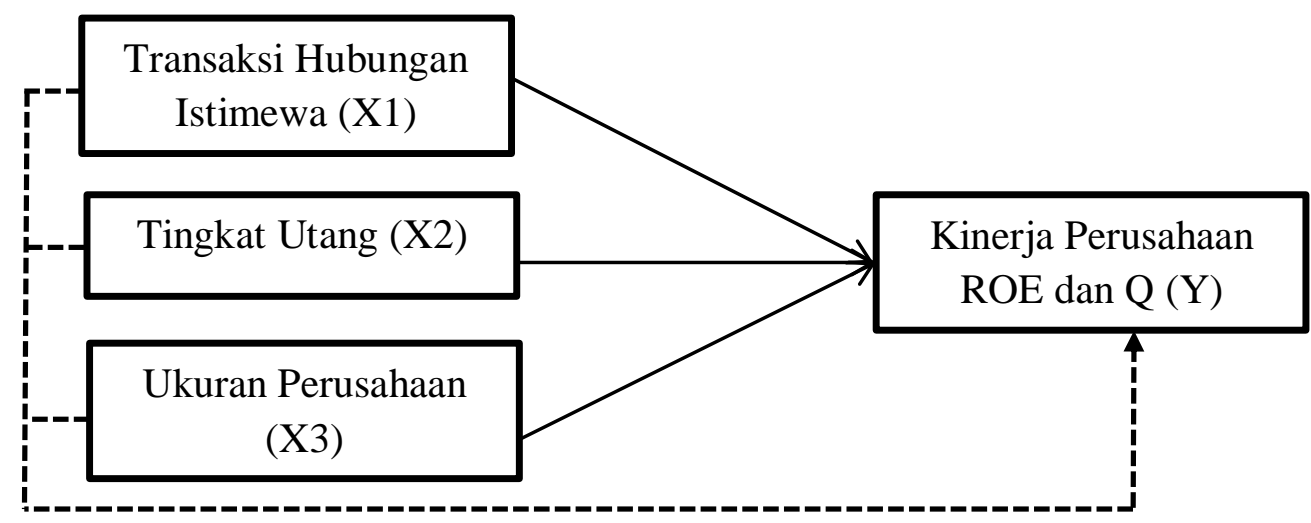

\subsection{Hipotesis}

Penelitian tentang topik ini sudah banyak dilakukan tetapi masih sedikit dilakukan di Indonesia. Hasil dari penelitian-penelitian tersebut pun berbeda-beda. Menurut Jian \& Wong (2003), Aharony, Lee \& Wong (2000) dan McCahery \& Vermeulen (2014) transaksi hubungan istimewa merupakan transaksi yang memicu timbulnya tunneling atau pengalihan kekayaaan dari pemegang saham minoritas kepada pemegang saham mayoritas, bahkan memberikan insentif dalam melakukan manajemen laba oleh insider baik sebelum dilakukannya IPO maupun setelah dilakukannya IPO. Transaksi yang umumnya dilakukan adalah dengan melakukan pinjaman kepada anak perusahaan tanpa bunga dan tidak melakukan 
pelunasan sehingga berdampak pada kinerja anak perusahaan dan risiko investasi bagi pemegang saham terutama pemegang saham minoritas.

Berbeda dengan hasil penelitian sebelumnya, menurut Gordon, Henry, Reed \& Louwers (2007) dan Farahmita (2011) transaksi hubungan istimewa tidak mengacu pada perbuatan manajemen laba dan kecurangan yang dapat menurunkan nilai perusahaan. Bahkan Peng, Wei \& Yang (2011) \& Tsai, Chang \& Chang (2015) menilai transaksi ini dipandang sebagai solusi dalam mempertahankan aset melalui penurunan biaya modal dan efisiensi atas biaya operasional perusahaan. Penelitian pada perusahaan yang terdaftar dalam bursa Nigeria yang dilakukan oleh Umobong (2011) menyebutkan transaksi hubungan istimewa dianggap dapat meningkatkan kinerja keuangan perusahaan. Berdasarkan hal tersebut, peneliti menarik hipotesis sebagai berikut :

H1 : Transaksi hubungan istimewa berpengaruh signifikan dan positif terhadap ROE

$\mathrm{H} 2$ : Transaksi hubungan istimewa berpengaruh signifikan dan positif terhadap Q

Tingkat utang berperan sebagai pengawasan eksternal yang dilakukan oleh kreditur untuk memastikan adanya pelunasan utang oleh debitur. Sehingga dengan adanya pengawasan tersebut diharapkan kinerja perusahaan menjadi semakin baik. Menurut Gordon, Henry, \& Palia (2004) tingkat utang memiliki pengaruh positif terhadap kinerja perusahaan. Dalam penelitian Kohlbeck \& Mayhew (2004) dinyatakan pula bahwa dengan adanya tingkat utang, performa perusahaan akan semakin termonitor karena berkaitan dengan tingkat pengembalian kepada kreditor. Berdasarkan alasan tersebut, peneliti menarik hipotesis sebagai berikut :

H3 : Tingkat utang berpengaruh signifikan dan positif terhadap ROE

H4 : Tingkat utang berpengaruh signifikan dan positif terhadap Q

Ukuran perusahaan dapat berpengaruh positif maupun negatif terhadap kinerja perusahaan. Hal ini tergantung seberapa baik kebijakan-kebijakan yang ditetapkan dan dijalankan perusahaan. Menurut DeFond \& Park (1997); Chen \& Steiner (2000); Siallagan \& Mas Ud (2006); Berkman, Cole \& Fu (2007); Tsai, Chang \& Chang (2015) menyebutkan bahwa semakin besar perusahaan maka resiko yang dihadapi akan semakin tinggi dibandingkan dengan perusahaan kecil akibat semakin kompleksnya jenis transaksi yang dilakukan, sehingga mempengaruhi dalam nilai perusahaan. Sedangkan Sujoko \& Soebiantoro (2007) memiliki pendapat yang berbeda dimana investor akan lebih responsif terhadap perusahaan besar karena dianggap memiliki potensi besar dalam mengembangkan usahanya dibandingkan perusahaan kecil dan secara langsung akan mempengaruhi peningkatan nilai perusahaan. Berdasarkan hal tersebut, peneliti menarik hipotesis sebagai berikut :

H5 : Ukuran perusahaan berpengaruh signifikan dan positif terhadap ROE

H6 : Ukuran perusahaan berpengaruh signifikan dan positif terhadap Q

H7 : Transaksi hubungan istimewa, tingkat utang dan ukuran perusahaan secara simultan berpengaruh signifikan dan positif terhadap ROE

H8 : Transaksi hubungan istimewa, tingkat utang dan ukuran perusahaan secara simultan berpengaruh signifikan dan positif terhadap Q 
Vol.2, No. 1, Jan. 2019

\section{METODE RISET}

Penelitian ini bersifat konfirmasi atas hasil statistik terhadap hipotesis yang dibuat berdasarkan variabel-variabel penelitian. Dengan jenis penelitian deskriptif kuantitatif, peneliti akan menganalisa data berupa angka-angka secara statistik. Data sekunder yang berasal dari laporan keuangan tahunan perusahaan properti dan real estate yang terdaftar dalam Bursa Efek Indonesia (BEI) tahun 2015-2017 akan dijadikan populasi dalam penelitian ini.

Variabel-variabel operasional pada penelitian ini menggunakan kinerja perusahaan (KP) sebagai variabel dependent. Variabel dependent adalah variabel yang mendapat pengaruh dari adanya keberadaan variabel independent. Kinerja perusahaan akan diukur menggunakan model Tobin's Q yang telah dimodifikasi (Klapper dan Love, 2002) dan ROE. Modified Tobin's Q membagi total harga pasar ekuitas pada akhir periode dan debt dengan nilai buku aset pada akhir periode. Harga pasar ekuitas pada akhir periode merupakan hasil kali share closing price per 31 Desember dengan jumlah outstanding shares. Sedangkan debt adalah hasil pengurangan dari total utang dan persediaan dengan aset lancar.

Sedangkan ROE memberikan ide tentang bagaimana manajemen menginvestasikan modal perusahaan dalam bentuk ekuitas secara efisien agar dapat menghasilkan laba yang optimal dengan membagi nilai laba tahun berjalan dengan total ekuitas.

$$
\mathrm{Q}=\frac{\text { (year ended MV equity) }+ \text { DEBT }}{\text { year ended BV of asset }}
$$

Keterangan :

Q $\quad=$ Tobin's Q beredar

Year ended MV of equity = Harga penutupan saham $\mathrm{X}$ jumlah saham yang

DEBT = $($ Total nilai buku utang + persediaan $)-$ aktiva lancar

Year ended BV of asset $=$ Total nilai buku aset

$$
\text { ROE }=\frac{\text { Laba bersih tahun berjalan }}{\text { Total ekuitas }}
$$

Transaksi hubungan istimewa atau Related Party Transaction (RPT) dalam penelitian ini akan berperan sebagai variabel independent, yaitu variabel yang mempengaruhi variabel lain. RPT akan dihitung berdasarkan daftar total transaksi-transaksi yang berkaitan dengan pihak-pihak yang mempunyai hubungan istimewa selama periode pelaporan, , baik berasal dari aktivitas piutang, utang, penjualan, pembelian, dan lainnya, (Okoro \& Jeroh, 2016; Umobong, 2017). Selain itu, dalam penelitian ini akan menggunakan variabel independent lainnya yaitu tingkat utang atau leverage (LEV) dan ukuran perusahaan (SIZE). 
Tingkat utang atau leverage dipilih sebagai mekanisme kontrol dalam meminimalisir penyelewengan transaski hubungan istimewa. Pada penelitian ini tingkat utang diukur dengan menggunakan leverage ratio, yaitu membandingkan jumlah liabilitas jangka pendek dan liabilitas jangka panjang dengan jumlah aset lancar dan aset tidak lancar. Sedangkan penggunaan log natural (ln) terhadap nilai total aset digunakan untuk mengurangi skewness dalam mengukur ukuran perusahaan ukuran. Adapun digunakannya total aset dikarenakan dapat memberikan gambaran atas penguasaan jumlah sumber daya sebagai akibat dari peristiwa ekonomi selama perusahaan beroperasi.

Peneliti menggunakan non-probability sampling dengan metode purposive sampling untuk pengumpulan data dengan mempertimbangkan beberapa kriteria yang dipilih. Adapun kriteria pengambilan sample dalam penelitian ini adalah:

1. Perusahaan properti dan real estate yang terdaftar di BEI tahun 2015-2017

2. Laporan keuangan tahunan yang diterbitkan secara berturut-turut tahun 20152017

3. Terdapat transaksi hubungan istimewa selama periode berjalan tahun 20152017

4. Terdapat informasi yang berkaitan dengan tingkat utang dan total aset (ukuran perusahaan) tahun 2015-2017

5. Terdapat informasi mengenai harga penutupan saham dan jumlah saham yang beredar selama 2015-2017

6. Terdapat informasi mengenai laba tahun berjalan dan jumlah ekuuitas selama 2015-2017

Metode yang digunakan adalah analisis regresi dan korelasi dengan menggunakan kriteria uji asumsi klasik dan uji statistik. Adapun model yang diterapkan adalah :

Model

Nilai Perusahaan

$=($ year ended MV equity $)+$ DEBT year ended $\mathrm{BV}$ of asset

Nilai Perusahaan

$$
=\alpha+\beta 2 \text { TRANS }+\beta 2 \mathrm{LEV}+\beta 2 \mathrm{SIZE}+\varepsilon
$$

Keterangan :

$\alpha$

TRANS

LEV

SIZE

$\varepsilon$

year ended $M V$ equity

DEBT
$=$ Intercept

$=$ Transaksi hubungan istimewa

$=$ Tingkat utang

= Ukuran Perusahaan

$=$ Error

= Harga penutupan saham $\mathrm{x}$ jumlah saham yang beredar

$=($ Total nilai buku utang + persediaan $)-$ aktiva

lancar 
Vol.2, No. 1, Jan. 2019

\section{ANALISIS DATA}

Metode analisis data akan menggunakan program aplikasi SPSS 23 dengan tahapan uji statistik deskriptif, uji asumsi klasik dan uji hipotesis. Uji asumsi klasik terdiri dari beberapa prosedur pengujian, yaitu i) uji normalitas, ii) uji multikolinearitas, iii) uji heterokedastisitas, dan iv) uji autokorelasi. Sedangkan uji hipotesis terdiri dari i) uji koefisien determinasi, ii) uji signifikansi $\mathrm{F}$, dan iii) uji parsial t.

Berdasarkan kriteria penelitian, total 48 perusahaan properti dan real estate yang terdaftar di BEI dalam kurun waktu 2015-2017, tercatat hanya 21 perusahaan yang memenuhi kriteria yang telah ditentukan. Dengan kata lain dalam penelitian ini menggunakan total sample 63 perusahaan properti dan real estate

\subsection{Statistik Deskriptif}

Uji statistik deskriptif memberikan gambaran mengenai kualitas data penelitian melalui angka yang tertera pada nilai standar deviasi dan mean. Pada tabel di bawah menunjukkan nilai standar deviasi transaksi hubungan istimewa tercatat 1656466,318 dan nilai mean sebesar 582367,8413. Hal ini menunjukkan data yang ditampilkan oleh variabel tersebut bervariasi atau heterogen. Sama halnya dengan transaksi hubungan istimewa, ROE dan Q memiliki data yang lebih beragam yaitu nilai standar deviasi yang lebih besar dibandingkan nilai mean. Sedangkan tingkat utang dan ukuran perusahaan terdiri dari data-data yang cenderung homogen. Hal ini dapat dilihat dari nilai mean sebesar 0,3284 dan 12,5919 lebih besar dibandingkan 0,18987 dan 0,69430.

Tabel 1. Statistik Deskriptif

\begin{tabular}{|l|c|c|c|c|c|}
\hline & Q & ROE & RPT & \multicolumn{1}{c|}{ LEV } & \multicolumn{1}{c|}{ SIZE } \\
\hline Mean & 0,2724 & 0,0535 & 582367,8413 & 0,3284 & 12,5919 \\
\hline Standar deviasi & 0,50872 & 0,06449 & 1656466,318 & 0,18987 & 0,69430 \\
\hline $\mathrm{N}$ & $63 \mathrm{HT}$ & $63 \mathrm{HT}$ & $63 \mathrm{HT}$ & $63 \mathrm{HM}$ & $63 \mathrm{HM}$ \\
\hline
\end{tabular}

Sumber Hasil Olah Data SPSS 23

\subsection{Uji Asumsi Klasik} hasil bahwa:

Dari hasil olah data pada SPSS 23 dalam pengujian asumsi klasik, diperoleh

1. Untuk melakukan uji normalitas dilakukan dengan beberapa metode yaitu Kolmogrov-Smirnov (K-S) dan grafik P-Plot. Hasil dari kedua metode tersebut dapat disimpulkan data-data penelitian terdistribusi secara normal. Nilai absolut (K-S) variabel lebih kecil dibandingkan nilai (K-S) tabel. Dengan tingkat signifikansi 0,05 pada $n=60$, maka nilai $(K-S)$ tabel diperoleh 0.172. Berdasarkan tampilan grafik P-Plot terlihat titik-titik penyebaran yang tidak jauh dari sekitar garis diagonalnya.

2. Tidak terdapatnya multikolinearitas pada data penelitian yang berarti tidak adanya hubungan yang erat antar variabel independent. Hal ini dapat 
dilihat dari nilai VIF masing-masing variabel independent lebih kecil dari 10 dan nilai toleransi di atas 0,10 .

3. Hasil uji heterokedastisitas menunjukkan tidak adanya kesamaan variance dan residual dari satu pengamatan ke pengamatan lainnya. Pada grafik plot terlihat titik-titik menyebar di atas dan di bawah angka 0 pada sumbu Y.

Pada uji autokorealitas, diperoleh nilai Durbin Watson (DW) 1,694 untuk ROE dan 1,010 untuk Q dimana nilai tersebut berada diantara +2 dan -2 . Hal ini dapat disimpulkan bahwa tidak terdapat autokorelasi pada data penelitian.

\subsection{Uji Hipotesis}

\subsubsection{Uji Koefisien Determinasi}

Berdasarkan hasil olah data statistik pada variabel-variabel penelitian dengan ROE sebagai pengukuran variabel independent kinerja perusahaan, maka diperoleh nilai Adjusted $R$ Square sebesar 0,296 atau sebesar 29,6\% variabel ROE dapat dijelaskan oleh variabel RPT, LEV dan SIZE. Sebesar 70,4\% dijelaskan oleh faktor-faktor lain. Sedangkan dengan menggunakan pengukuran $Q$ atas kinerja perusahaan, 31,3\% dapat dijelaskan oleh variabel RPT, LEV dan SIZE.

\subsubsection{Uji Parsial t}

Berdasarkan hasil uji parsial $\mathrm{t}$ diperoleh hasil bahwa tingkat utang dan ukuran perusahaan memiliki pengaruh signifikan dan positif terhadap kinerja perusahaan yang diukur dengan ROE atau dengan kata lain hipotesis diterima. Hal ini dibuktikan dengan nilai t hitung kedua variabel yang lebih besar dibandingkan dengan t tabel. Selain itu nilai signifikansi kedua variabel berada dibawah nilai signifikansi 0,05. Berbeda dengan tingkat utang dan ukuran perusahaan, transaksi hubungan istimewa tidak berpengaruh signifikan terhadap kinerja perusahaan yang diukur dengan ROE atau hipotesis ditolak. Adanya transaksi hubungan istimewa tidak mempengaruhi profitabilitas perusahaan. Transaksi ini dianggap bukan sebagai metode untuk melakukan efisiensi dalam pengelolaan aset perusahaan ataupun dijadikan alat untuk mengeksprpriasi kekayaan pemegang saham minoritas kepada pemegang saham mayoritas.. Hasil ini juga tidak sama dengan hasil yang diperoleh Umobong (2017) pada perusahaan yang terdaftar dalam bursa Nigeria, dimana transaksi hubungan istimewa berpengaruh dan positif terhadap kinerja keuangan perusahaan yang diukur dengan Return on Asset (ROA), ROE, dan Earning per Share (EPS).

Tingkat utang berpengaruh signifikan dan positif terhadap ROE menunjukkan semakin meningkatnya tingkat utang mengindikasikan semakin ketatnya pengawasan manajemen sehingga menyebabkan adanya peningkatan dalam kinerja perusahaan (Myers, 2001). Hasil ini juga didukung oleh penelitian Ludijanto, Handayani \& Hidayat (2014); Sulong et al (2013); Kohlbeck \& Mayhew (2004). Hasil yang sama diperoleh variabel ukuran perusahaan, semakin besar ukuran perusahaan menunjukkan adanya pertumbuhan yang tentunya akan berdampak pada peningkatan respon positif oleh investor dan nilai perusahaan (Sujoko \& Soebiantoro, 2007).

Ukuran perusahaan berpengaruh positif terhadap ROE menunjukkan semakin besar ukuran perusahaan maka akan berdampak semakin baiknya kinerja 
perusahaan. Besarnya ukuran perusahaan yang menandai besarnya total aset yang dimiliki sehingga memiliki kesempatan untuk mengembangkan usahanya untuk memperoleh laba yang lebih besar. Hasil ini didukung oleh penelitian yang dilakukan Prijanto, Veno \& Chuzaimah (2017); Arisadi, Djumahir, \& Djazuli (2013) dimana perusahaan besar memiliki fleksibilitas dan akses untuk memperoleh sumber dana darimanapun untuk membiayai investasinya.

Pada hasil uji regresi terhadap kinerja perusahaan yang diukur dengan Tobin's Q, diperoleh hasil bahwa ketiga variabel independent berpengaruh signifikan terhadap kinerja perusahaan. Transaksi hubungan istimewa memiliki pengaruh sigifikan dan postif atas $\mathrm{Q}$ atau hipotesis diterima. Pasar memandang transaksi hubungan istimewa merupakan metode perusahaan dalam menjaga aset perusahaan dari kemungkinan adanya pengambilalihan aset kepada pihak ketiga (Tsai, Chang dan Chang, 2015; Peng, Wei dan Yang, 2011). Hasil ini juga didukung oleh studi yang dilakukan oleh Farahmita (2011) dimana tidak adanya indikasi tindakan oportunistik manajemen laba yang dapat berdampak penurunan kinerja perusahaan pada transaksi hubungan istimewa seperti hasil yang diperoleh pada penelitian Farahmita (2011). Buysschaert (2004) menemukan bahwa transfer ekuitas intergroup dapat meningkatkan nilai bagi pemegang saham non pengendali.

Tingkat utang memiliki pengaruh signifikan dan positif terhadap Q, dengan kata lain hipotesis diterima. Hal ini dapat terlihat dari t hitung yang lebih besar dibandingkan t tabel senilai 2,00030. Hasil ini sama dengan hasil yang diperoleh dengan menggunakan ROE, dimana menurut Gordon, Henry dan Palia (2004) tingkat utang mewakili kreditur akan meningkatkan pengawasannya terhadap dana yang dipinjamkan kepada debitur agar adanya kepastian dalam melakukan pelunasan atas pinjaman sehingga diharapkan kinerja perusahaan menjadi semakin baik. Hasil penelitian ini juga didukung oleh hasil penelitian Kristianti (2018) dimana nilai utang yang semakin besar menandakan sumber dana yang tersedia semakin banyak untuk memaksimalkan kesempatan bisnis sehingga akan berdampak pada peningkatan laba perusahaan yang tentunya juga akan berdampak pada peroleh pendapatan bagi pemegang saham melalui pembagian deviden. Akan tetapi hasil ini tidak sejalan dengan hasil yang diperoleh dalam penelitian Kristiana (2014); Dirgantara \& Lubis (2013) dimana semakin besar utang akan mengakibatkan penurunan kinerja perusahaan.

Dengan nilai -t hitung < -t tabel $(-2,878<-2,00030)$ menandakan ukuran perusahaan berpengaruh signifikan dan negatif terhadap Tobin's Q, dengan kata lain hipotesis ditolak. Hasil ini sesuai dengan hasil yang diperoleh dalam penelitian Chen dan Steiner (2000); Siallagan dan Mas Ud (2006) yaitu semakin besar perusahaan maka problema, resiko dan kompleksitas transaksi yang dimiliki semakin besar dan beragam sehingga akan berdampak pada penurunan kinerja perusahaan. Pada hasil penelitian Berkman et al (2007) menunjukkan bahwa semakin besar skala perusahaan kemungkinan terjadinya ekspropriasi melalui penerbitan related guarentees yang akan menyebabkan performa perusahaan dinilai negatif. 
Tabel 2. Uji Parsial t

\begin{tabular}{|c|c|c|c|}
\hline $\begin{array}{c}\text { Variabel } \\
\text { Dependent }\end{array}$ & $\begin{array}{c}\text { Variabel } \\
\text { Independent }\end{array}$ & T & Signifikansi \\
\hline ROE & RPT & $-0,588$ & 0.559 \\
& LEV & 2,291 & 0.026 \\
& SIZE & 2,704 & 0.009 \\
\hline Q & RPT & 2.888 & 0.005 \\
& LEV & 5,102 & 0.000 \\
& SIZE & $-2,878$ & 0.006 \\
\hline
\end{tabular}

Sumber Hasil Olah Data SPSS 23

\subsubsection{Uji Simultan F}

Hasil analisis regresi menyatakan bahwa variabel independen transaksi hubungan istimewa, tingkat utang dan ukuran perusahaan secara simultan mempengaruhi kinerja perusahaan yang diukur baik dengan ROE maupun Tobin's Q dengan tingkat signifikansi $0 \%$ di kedua hasil pengolahan data. F hitung pada ROE tercatat 9,675 dan 10,429 pada Tobin's Q. Ini menunjukkan model penilitian tersaji dengan baik dan hipotesis diterima.

Tabel 3 Uji Simultan F

\begin{tabular}{|c|c|c|c|}
\hline $\begin{array}{c}\text { Variabel } \\
\text { Dependent }\end{array}$ & $\begin{array}{c}\text { Variabel } \\
\text { Independent }\end{array}$ & F & Signifikansi \\
\hline \multirow{2}{*}{ ROE } & $\begin{array}{l}\text { RPT } \\
\text { LEV }\end{array}$ & 9,675 & 0.000 \\
\hline \multirow{2}{*}{ SIZE } & RPT & 10,429 & 0,000 \\
\hline & $\begin{array}{l}\text { LEV } \\
\text { SIZE }\end{array}$ & & \\
\hline
\end{tabular}

Sumber Hasil Olah Data SPSS 23

\subsection{Kesimpulan}

Penelitian yang dilakukan dengan populasi perusahaan property dan real estate yang terdaftar di BEI tahun 2015-2017 bertujuan untuk mengetahui pengaruh antara variabel independent, yaitu transaksi hubungan istimewa, tingkat utang dan ukuran perusahaan dengan variabel dependent kinerja perusahaan. Adapun kinerja perusahaan diukur dengan dua metode yaitu metode pasar Tobin's $\mathrm{Q}$ dan metode akuntansi ROE.

Dari hasil olah data statistik, dapat disimpulkan bahwa transaksi hubungan istimewa tidak berpengaruh pada kinerja perusahaan yang diukur dengan ROE. Dengan metode akuntansi, adanya transaksi hubungan istimewa tidak mempengaruhi profitabilitas perusahaan. Transaksi ini dianggap bukan sebagai metode untuk melakukan efisiensi dalam pengelolaan aset perusahaan ataupun dijadikan alat untuk mengeksprpriasi kekayaan pemegang saham minoritas kepada pemegang saham mayoritas. Berbeda dengan hasil sebelumnya, transaksi hubungan istimewa berpengaruh positif terhadap kinerja perusahaan yang diukur dengan Tobin's Q. Pasar memandang transaksi hubungan istimewa merupakan 
metode perusahaan dalam menjaga aset perusahaan dari kemungkinan adanya pengambilalihan aset kepada pihak ketiga.

Kesimpulan pada variabel independent tingkat utang menghasilkan adanya pengaruh positif terhadap kinerja perusahaan baik dukur dengan ROE maupun Tobin's Q. Pasar maupun akuntansi menganggap tingkat utang berperan dalam peningkatan penilaian kinerja perusahaan. Tingkat utang merepresentasikan pinjaman yang diberikan oleh kreditur, akan meningkatkan pengawasan atas dana yang dipinjamkan akan mampu melunasi pinjamannya. Hal ini tentunya akan memaksa perusahaan untuk meningkatkan kinerjanya.

Dengan menggunakan variabel independent yang ketiga disimpulkan bahwa ukuran perusahaan berpengaruh positif terhadap kinerja perusahaan yang diukur dengan ROE, perusahaan dengan skala yang semakin besar dianggap pula memiliki potensi yang besar dalam mengembangkan usahanya dibandingkan perusahaan skala kecil. Selain itu, semakin kecil ukuran perusahaan menandakan perusahaan tersebut tidak mengalami perkembangan. Sedangkan ukuran perusahaan berpengaruh negative terhadap kinerja perusahaan yang diukur dengan Tobin's Q. Pasar menilai semakin kecil ukuran perusahaan maka akan semakin baik kinerjanya karena resiko yang muncul tidak banyak akibat masih sederhananya transaksi yang terjadi.

Dengan pengujian simulatan, ketiga variabel independent yaitu ,transaksi hubungan istimewa, tingkat utang dan ukuran perusahaan memiliki pengaruh terhadap kinerja perusahaan baik diukur dengan ROE maupun Tobin's Q.

\section{IMPLIKASI DAN KETERBATASAN}

\section{Implikasi}

Terdapat implikasi yang muncul dari penelitian ini:

1. Menurut pasar, besarnya transaksi hubungan istimewa memiliki pengaruh yang baik terhadap penilaian kinerja perusahaan sedangkan menurut akuntansi tidak berpengaruh terhadap kinerja.

2. Baik pasar maupun secara akuntansi, besarnya utang perusahaan akan berbanding lurus dengan kinerja perusahaan

3. Pasar menilai besarnya ukuran perusahaan akan berdampak positif terhadap kinerja perusahaan tetapi menurut akuntansi akan berdampak negatif bagi kinerja perusahaan

\section{Keterbatasan dan Saran}

Dalam melakukan penelitian ini, peneliti tidak lepas dari keterbatasanketerbatasan, berikut pemaparan beserta saran yang diberikan peneliti untuk penelitian selanjutnya:

1. Penelitian ini hanya fokus pada besaran transaksi hubungan istimewa yang terjadi dalam suatu perusahaan tanpa melihat jenis transaksi apakah (penjualan,pembelian, piutang dan utang) yang berdampak secara langsung terhadap penilaian perusahaan. Peneliti selanjutnya dapat meneliti pengaruh RPT dengan nilai perusahaan berdasarkan jenis transaksinya 
2. Penelitian ini tidak melihat apakah transaksi hubungna istimewa berasal dari perusahaan dengan family ownership atau tidak. Diharapkan peneliti selanjutnya dapat meneliti hubungan transaksi hubungan istimewa dengan nilai perusahaan dengan membedakan apakah perusahaan tersebut family ownership atau public ownership

3. Penelitian ini hanya menggunakan masing-masing salah satu metode pengukuran kinerja keuangan yaitu ROE dan Tobin's Q. Diharapkan penelitian selanjutnya dapat menggunakan pengukuran kinerja lainnya seperti ROA untuk metode akuntansi dan Efficient Response Coefficient (ERC).

\section{DAFTAR PUSTAKA}

Aharony, J., Lee, C.W.J., \& Wong, T.J. (2000). Financial packaging of IPO firms in China. Journal of Accounting Research, 38, 103-126.

Animah \& Ramadhani, R. S. (2010). Pengaruh Struktur Kepemilikan, Mekanisme Corporate Governance dan Ukuran Perusahaan terhadap Nilai Perusahaan (Survei pada Perusahaan Manufaktur yang terdaftar di Bursa Efek Jakarta 2003-2007). Tesis dipublikasikan. Universitas Hasanudin.

Arisadi, Y. C, Dzumahir \& Djazuli, Atim (2013). Pengaruh Ukuran Perusahaan, Umur Perusahaan, Current Ratio, Debt to Equity Ratio dan Fixed Asset Total Asset Ratio terhadap Kinerja Keuangan pada Perusahaan Manufaktur di Bursa Efek Indonesia. Jurnal Aplikasi Manajemen, Vol. 11, No. 4

Berkman, Henk, Cole, R. A. \& Fu, L. J. (2007). Expropriation Through Loan Guarantees to Related Parties: Evidence from China. Available at SSRN 1305217.

Buysschaert, A., Deloof, M. \& Jegers, M. (2004). Equity sales in Belgian corporate groups. Expropriation of minority shareholders? A clinical study. Journal of Corporate Finance, Vol. 10, No. 1, 2004, pp. 81-103

Chen, C., \& T. Steiner. (2000). Tobin's Q, Managerial Ownership, and Analyst Coverage: A Nonlinear Simultaneous: A Nonlinear Simultaneous Equations Model. Journal of Economics and Business 52: 365-382.

DeFond, M. L., \& Park, C. W. (1997). Smoothing income in anticipation of future earnings. Journal of Accounting and Economics, 23(2), 115-139.

Dirgantara, K. A \& Lubis, A. W. (2013). Pengaruh Perubahan Tingkat Utang terhadap Tingkat Pengembalian Saham, Investasi, dan Kinerja Masa Depan Perusahaan yang Tercatat di Bursa Efek Indonesia 2007-2011. Jurnal Manajemen

Farahmita, Aria. (2011). Apakah transaksi hubungan istimewa merupakan insentif untuk melakukan manajemen laba?. Simposium Akuntansi Nasional XIV.

Gordon, E. A., Henry, E. \& Palia, D. (2004). Related party transactions and corporate governance. Advances in Financial Economics, Vol. 9, pp. 128. 
Gordon, E. A. \& Henry, E. (2005). Related Party Transaction and Earnings Management. Available at SSRN 612234

Gordon et al. (2007). The Role of Related Party Transactions in Fraudulent Financial Reporting. Available at SSRN 993532

Hayati, Namira. (2011). Apakah transaksi pihak hubungan istimewa merupakan insentif untuk meningkatkan profitabilitas?. Jurnal Akuntansi.

Ikatan Akuntan Indonesia. (2009). Pernyataan Standar Akuntansi Keuangan (PSAK). Jakarta: Salemba Empat.

James C. Van Horne \& John M. Wachowicz, Jr. (1998) .Prinsip-prinsip Manajemen Keuangan. Buku 2. Edisi 9. Penerjemah Heru Sutojo. Jakarta : Salemba Empat. 